\title{
Ossifying Pituitary Adenoma Co-existing with Astrocytoma and Pituitary Adenoma Associated with Gangliocytoma: Two Unusual Conditions
}

\author{
Kemikleşmekte Olan Hipofiz Adenomu ile Birlikte Görülen Astrositoma \\ ve Hipofiz Adenomu ile Illişkili Gangliositoma: Alışılmadık İki Koşul
}

Sushila JAISWAL ${ }^{1}$, Mukul VIJ ${ }^{1}$, Awadhesh Kumar JAISWAL ${ }^{2}$, Gyan CHAND ${ }^{3}$, Sanjay BEHARI ${ }^{2}$, Vijendra Kumar JAIN ${ }^{2}$

${ }^{1}$ Sanjay Gandhi Postgraduate Institute of Medical Sciences, Department of Pathology, Lucknow, India

${ }^{2}$ Sanjay Gandhi Postgraduate Institute of Medical Sciences, Department of Neurosurgery, Lucknow, India

${ }_{3}^{3}$ Sanjay Gandhi Postgraduate Institute of Medical Sciences, Department of Endocrine Surgery, Lucknow, India

Correspondence address: Sushila JAISWAL / E-mail: sushilapath@yahoo.com

\begin{abstract}
Bone formation in pituitary adenoma is an extremely rare finding. Only five previous cases have been published. This is the sixth case report of an ossifying pituitary adenoma and the first case report of a pituitary adenoma with bone formation coexisting with WHO grade II astrocytoma. MRI imaging revealed an unusual eggshell cap-like calcified structure surrounding the tumor. Histologically, the adenoma contained irregularly anastomosing trabeculae with well-formed lacunae and osteoblasts along the margins. Our second case concerns a 25 -year-old male patient who presented with complains of off and on headache for 12 months. MRI (head) revealed a $4 \times 3 \mathrm{~cm}$ well defined rounded lesion in the sella and suprasellar extension that was isointense in T1, hyperintense on T2 with cystic areas and homogenous contrast enhancement. On morphological examination, a cellular tumor admixed with foci of large ganglion cells embedded in a neuropil stroma was noted. On immunohistochemistry, tumor cells were focally positive for pancytokeratin, growth hormone and synaptophysin; and ganglion cells were positive for neurofilament and synaptophysin. No GFAP positive cells were seen. The Ki67 index was $<1 \%$. Based on these findings, a diagnosis of gangliocytoma associated with pituitary adenoma was considered.
\end{abstract}

KEYWORDS: Pituitary, Pituitary adenoma, Bone formation, Astrocytoma, Gangliocytoma

öz

Hipofiz adenomlarında kemik oluşumu oldukça nadir görülen bir bulgudur. Toplam 5 hipofiz adenomu olgusunda kemikleşme oluşumu rapor edilmiştir. Sunulan ilk vaka kemikleşme gösteren hipofiz adenomu olması yanı sıra gonadotropin üreten bir hipofiz adenomu ve grade 2 astrositom ile birlikteliği ile bu özellikteki ilk olgu sunumudur. Manyetik rezonans görüntülemede; kemik dokusunun hipofiz adenomunun etrafını yumurta kabuğu gibi sardığı görüldü. Histolojik olarak adenomanın düzensiz bir şekilde birbiri ile ilişkili trabeküler yapılar yanı sıra; iyi gelişmiş lakünler ve osteoblastları da içerdiği görüldü. Diğer vaka ise 25 yaşında erkek hasta 1 yıldan bu yana ara sıra olan başağrıları nedeni ile çekilen manyetik görüntülemesinde sella ve parasellar bölgede $4 \times 3 \mathrm{~cm}$ 'lik iyi sınırlı, oval görünümlü ve T1 kesitlerde isointens, T2 kesitlerde hiperintens görünümün yanı sıra kistik alanlar ve homojen kontrast tutulumu izlendi. Morfolojik incelemede, nöropil doku içerisinde ganglion hücre odakları görüldü. İmmunohistokimya çalışmasında tümör hücrelerinin pansitokeratin, büyüme hormonu ve sinaptofizin ile fokal olarak pozitif reaksiyon verdiği görüldü. Ganglion hücreleri nörofilament ve sinaptofizinle pozitif reaksiyon verdi. GFAP ile tutulum görülmedi. Ki 67 indeksi yüzde 1'in altında idi. Bu bulguların ışığında gangliositoma ile ilişkili hipofiz adenomu olgusu tanısı konulmuştur.

ANAHTAR SÖZCÜKLER: Hipofiz, Hipofiz adenomu, Kemik oluşumu, Astrositoma, Gangliositoma

\section{INTRODUCTION}

Pituitary adenoma is a common tumor in the sellar region, representing approximately $10-15 \%$ of intracranial tumors. Prolactinoma is the most common type, comprising approximately $25 \%$ of pituitary adenomas (2). Calcification in pituitary adenoma is detected in $0.2 \%$ to $14 \%$ of cases (4). Intratumoral pituitary stone has also rarely been described (25). However, the ossification of pituitary adenomas is extremely rare and has been described just five times in literature $(10,16,17,19,26)$. Bone formation in the pituitary gland was first described by Shanklin, with an incidence of $1 \%$, based on the results of an autopsy case series (21). The current case report is of ossification in a pituitary adenoma in an acromegaly patient with co-existing WHO grade II astrocytoma. Though pituitary adenoma with low grade astrocytoma has been reported four times earlier $(1,6,9,24)$, this is the first case report of acromegaly producing ossified pituitary adenoma with WHO grade II astrocytoma . 
Gangliocytoma is defined as a tumor composed of neoplastic mature ganglion cells (2). These neuronal or ganglion cellcontaining neoplasms of the pituitary gland are benign neoplasms that have been infrequently described. Kiyono et al first described this lesion in 1926 (12). Since publication of the first report, these lesions have been described under a variety of terms such as ganglioneuroma, ganglioneurocytoma with adenoma, gangliocytoma, gangliocytoma with adenoma, neural or neurnal adenohypophyseal choristoma and pituitary adenoma with neuronal choristoma (PANCH) (23). The histogenesis of neoplastic ganglion cells in pituitary adenomas has been debated. Most of the cases mentioned in the literature have occurred in the setting of acromegaly/ gigantism, wherein patients have presented with the clinical, radiological and endocrinological features of a typical growth hormone-producing pituitary adenoma. In other instances, they have resulted in other adenohypophyseal endocrine abnormalities such as Cushing disease or galactorrhoea (23). Our second case is an uncommon case of gangliocytoma associated with pituitary adenoma.

\section{CASE 1}

\section{Patient history and physical examination}

Our first case concerns a 48-year-old female who presented at the Neurosurgery outpatient department with complaints of holocranial headache, excessive watering from eyes and coarsening of facial features with enlargement of hands and feet for 15 years. She had developed progressive diminution of vision in both eyes for five years with rapid deterioration for the last year along with a bitemporal field defect for 2 years and had then developed repeated attacks of generalized tonic clonic seizure for the last eight months. The patient was a known case of diabetes mellitus and hypertension and was on insulin and had experienced secondary amenorrhea. On physical examination, she had acromegalic features. Her MRI (head) revealed a lesion in the sellar and suprasellar region extending to the left parasellar area and measuring $3.3 \times 3.0 \times 2.0$ $\mathrm{cm}$ (Figure 1A). The optic chiasma was stretched over the surface of the tumor superiorly. The left lateral internal carotid artery was encased by the tumor which was extending to he cavernous sinus. The lesion was isointense on T1- and T2weighted images and was enhancing heterogeneously on contrast. The normal pituitary was not visualized separately and an ill-defined mass was also noted in the left temporal region (Figure 1B). It was hypointense on $\mathrm{T} 1$ and hyperintense on T2 with minimal patchy enhancement. Other laboratory parameters included growth hormone $(\mathrm{GH})$ suppression test at 0 minute $>34.7 \mathrm{ng} / \mathrm{ml}$, and at 60 minute, $>34.7 \mathrm{ng} / \mathrm{ml}$. The insulin-like growth factor type I (IGF-1) level was markedly elevated with values of $724.6 \mathrm{nmol} / \mathrm{l}$. Serum prolactin level was $244.0 \mathrm{~min} / \mathrm{l}$ and serum T4 was $106.2 \mathrm{nmol} / \mathrm{l}$.

\section{Operative findings}

Left fronto-temporal craniotomy was performed and the pituitary adenoma was excised by the trans-sylvian route. The pituitary tumor was soft, suckable and vascular. Gross total tumor was removed leaving behind the capsule. During tumor removal, the part of calcified tumor was identified and was removed in toto (Figure 2). The intra-operative impression was of a pituitary adenoma. For the temporal lobe glioma, temporal lobectomy was performed. The tumor was soft, suckable, relatively avascular and ill-defined yellowish in colour. Intra-operative diagnosis of low grade astrocytoma was considered. The post-operative period of the patient was uneventful.

\section{Pathology findings}

Grossly, a grey white, soft nodular tumor tissue along with a hard ovoid egg-shell like structure from the sellar region was submitted and measured $1.5 \times 1.4 \times 1.3 \mathrm{~cm}$ (Figure 2). The tissue was fixed in $10 \%$ buffered formalin for 12 hour, and then serial sections were taken and the whole tissue was processed. The hard and chalky texture was decalcified in 1\% trichloroacetic acid solution for 12 hours. Another tissue from the temporal
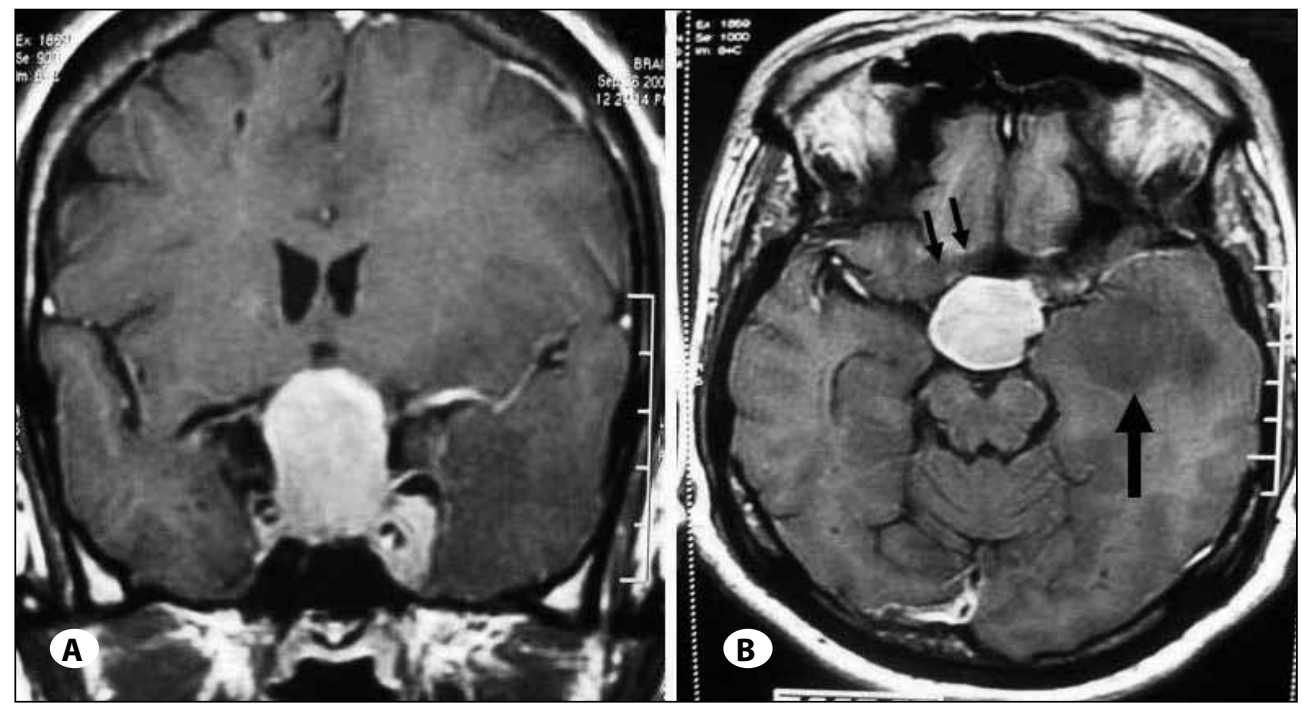

Figure 1: MR images of Case-1: A) Coronal section showing a large lesion in sellar and suprasellar area extending to the left parasellar area, B) Axial section of he same patient showing an ill-defined mass noted in the left temporal region (arrow) along with the pituitary adenoma (double arrow). 


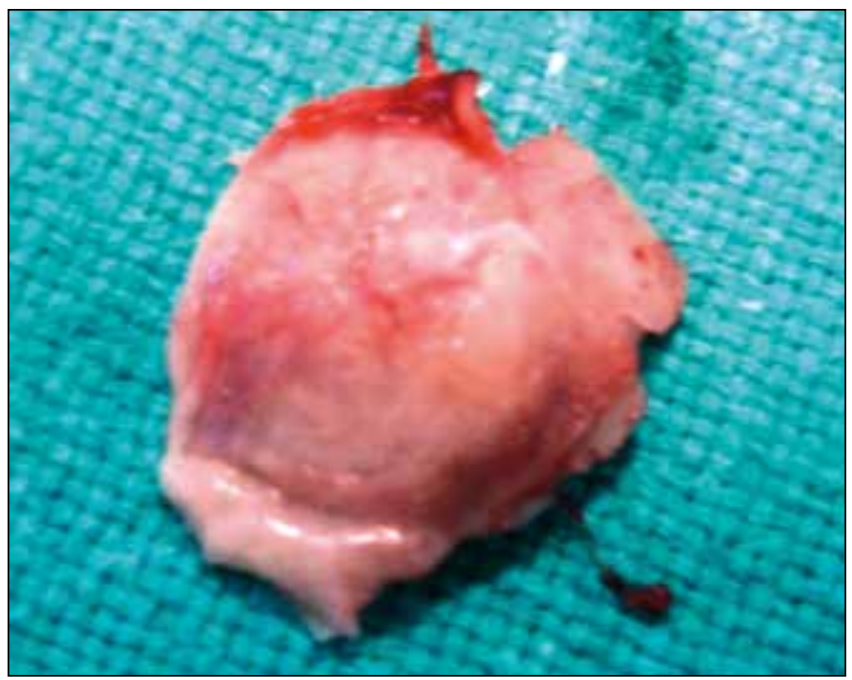

Figure 2: Showing intra-operative specimen of sellar tumor with egg shell like structure which on histology proved to be pituitary adenoma with bone formation in side the tumor.
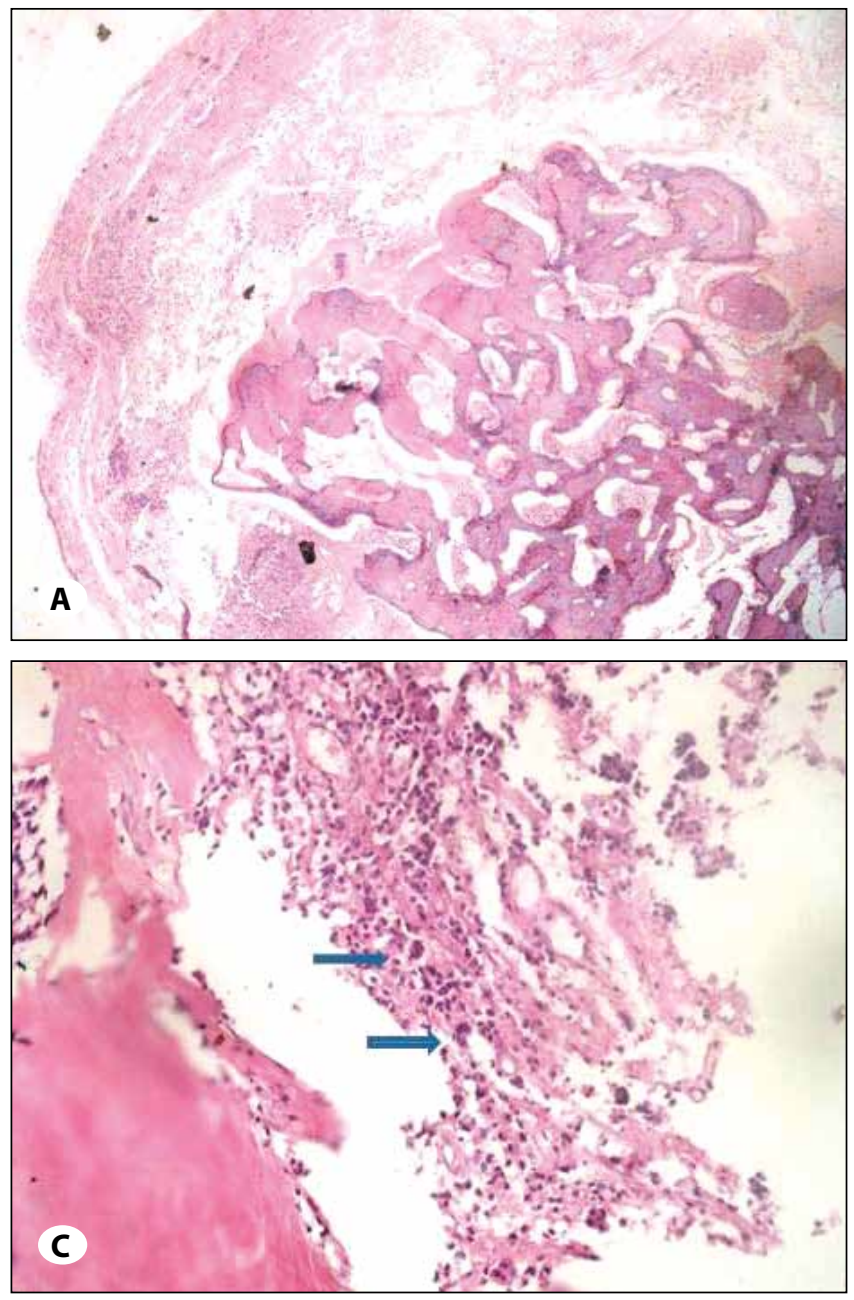

lobe tumor measuring $3 \times 2 \times 2 \mathrm{~cm}$ was also received and the whole tissue was processed. Light microscopy of the sellar tumor revealed that the tumor parenchyma was a welldemarcated lesion; most of the tumor parenchyma was replaced by the well-differentiated lamellar bone tissue. The tumor tissue was observed among the interwoven lamellar bony trabeculae (Figure 3A-C). The foci of myeloid metaplasia was also noticed (Figure $3 C$ ). In high-power view, the pituitary adenoma was comprised of round to ovoid neoplastic cells with eosinophilic to amphophilic cytoplasm and arranged in sheets traversed by fine vascular channels and nests among the mature bone trabeculae. No invasive growth pattern was seen in the parenchyma. No cellular atypia or necrosis was identified. Sections from the temporal lobe tumor revealed a WHO grade II astrocytic tumor. No mitosis or necrosis was noted (Figure 3D). On the basis of these findings, a diagnosis of ossifying pituitary adenoma co-existing with astrocytoma was made.
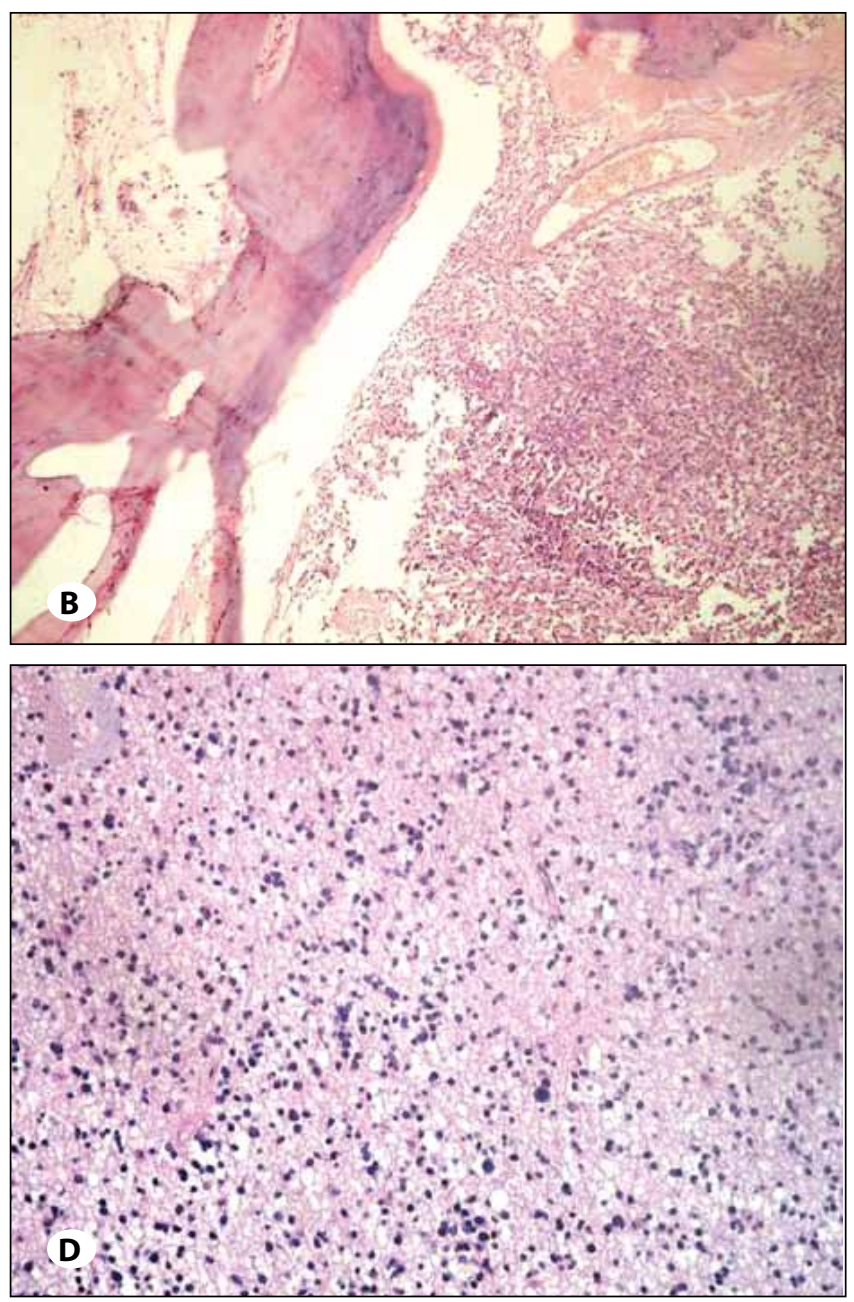

Figure 3: Photomicrograph of Case-1: A) pituitary adenoma with bone formation in the centre of the tumor, B) interface of pituitary adenoma and well differentiated lamellar bone, C) few megakaryocytes (arrow) and myeloid cells seen in the marrow, D) temporal lobe glioma showing increased cellularity against fibrillary background. No mitosis, necrosis or endothelial proliferations are noted (H\&E, x200). 


\section{CASE 2}

\section{Patient history and physical examination}

Our second case concerns a 25-year-old male patient who presented in the Neurosurgery outpatient department with complaints of off and on headache for 12 months, pain over both eyes along with increased tears for 10 months and thickening of hands and feet for six months. On physical examination his higher mental functions were intact and other neurological findings were within normal limits. Laboratory investigation revealed that the patient had a hemoglobin of $12.7 \mathrm{gm} \%$. MRI (head) revealed a $4 \times 3 \mathrm{~cm}$ well-defined rounded lesion in the sella and suprasellar extension that was isointense on $\mathrm{T} 1$, hyperintense on $\mathrm{T} 2$ with cystic areas and homogenous contrast enhancement (Figure 4). There was no hydrocephalus and no vascular/cavernous sinus involvement.

\section{Operative findings}

Sublabial rhinoseptal trans-sphenoidal tumor decompression was done. The tumor was soft, suckable, reddish white and mildly vascular. It had a cystic component. The intra-operative impression was of a pituitary adenoma.

\section{Pathology findings}

Grossly, multiple irregular tissue pieces altogether measuring $2 \times 1 \times 1 \mathrm{~cm}$ were received. On morphological examination, a cellular tumor admixed with foci of large ganglion cells embedded in neuropil stroma was noted. The tumor was composed of round tumor cells arranged in sheets. The tumor cell nuclei were mildly anisomorphic with finely distributed chromatin and moderate amount of eosinophilic cytoplasm (Figure 5A, B). No mitosis, necrosis, or atypia was noted. On immunohistochemistry, tumor cells were focally positive for pancytokeratin, neuron specific enolase, growth hormone and synaptophysin; and ganglion cells were positive for neurofilament and synaptophysin (Figure 5C, D and Figure $6 \mathrm{~A}, \mathrm{~B})$. No GFAP positive cells were seen. The Ki67 index was $<1 \%$. Based on these findings, a diagnosis of gangliocytoma associated with pituitary adenoma was considered.

\section{DISCUSSION}

Only five cases of pituitary adenoma with bone formation have been reported in the English literature $(10,16,17,19,26)$. Two of these were pre-menopausal women, presenting with prolactin producing adenoma and $\mathrm{GH}$-producing adenoma. The other two cases were reported in 1999, a 77-year-old man with gonadotrophin-producing adenoma and a growth hormone-secreting adenoma in a 56-year-old acromegalic woman. The fifth reported case of pituitary adenoma with ossification or osteo-metaplasia, was a prolactin-producing phenotype and presented with a long history of irregular menstruation. Our case was an acromegalic women with secondary amenorrhoea. To the best of our knowledge, our case is the first case in the literature, where a patient of pituitary adenoma simultaneously harbor a temporal lobe WHO grade II astrocytoma. Two case reports exist of non-functioning pituitary adenoma with pilocytic astrocytoma and one each

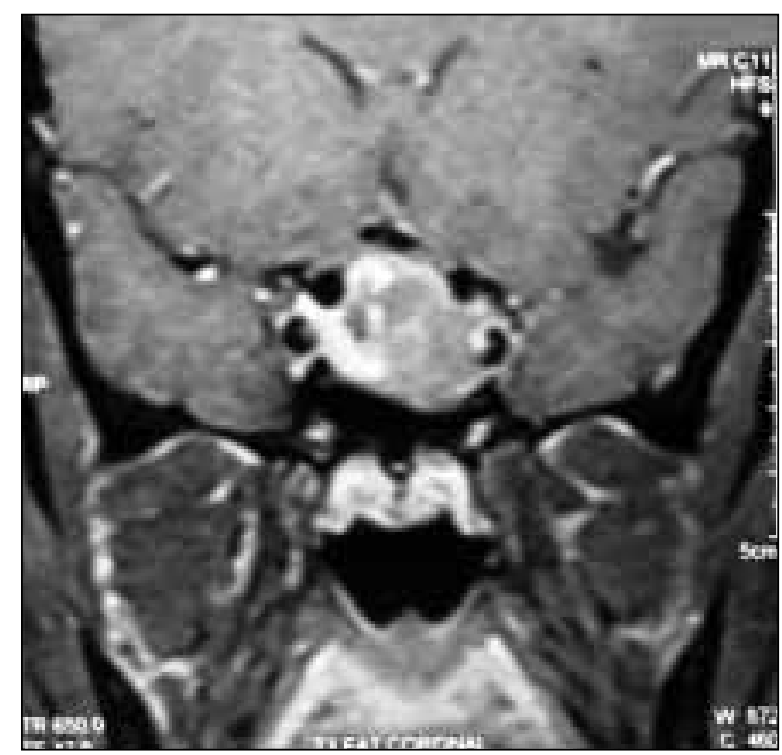

Figure 4: MR images of Case -2 showing well defined rounded lesion in sella and suprasellar area suggestive of pituitary adenoma.

of WHO grade II astrocytoma with nonfunctioning adenoma and TSH-producing adenoma $(1,6,9,24)$. Fernandez et al published the only case report of an anaplastic astrocytoma presenting in a patient with acromegaly (5). The current tumor showed a bony structure that is similar to the earlier three reports $(10,19,26)$. Microscopically, the round to oval neoplastic cells in moderate cellularities with eosinophilic cytoplasm were arranged in sheets and traversed by fine fibrovascular channels and distributed among anastomosing, well-differentiated lamellar bone trabeculae, showing the unique histological features. The histological characteristics are different from the case reported by Mukada et al that showed extensive ossification and only a few tumor cells among the ossified structures (16). Further, myeloid metaplastic foci were also observed in the parenchyma of the current tumor, suggesting maturity of osteoid metaplasia, which has only been described once by Ke et al (10).

The exact pathogenesis of ossification in pituitary adenomas needs to be elucidated. Numerous secreted factors of paracrine, autocrine, and endocrine origin influence the development and maturation of osteoblasts in the human body (11). The ossification associated with growth hormoneproducing adenoma in this case belongs to heterotopic ossification. Such ossification in pituitary adenoma was thought to be related to the mass compression effect and the increased intrasellar pressure induced by the tumor nodule, as was proposed by Palaoglu et al (17) However, Mukada et al. suggested that the intratumoral bleeding and secondary degeneration of tumor cells may initiate dystrophic ossification (16). This mechanism does not appear to be the condition in our case, since no degenerative changes and necrotic foci occurred within the parenchyma in our case. In the current case, secondary ischemia induced by tumor compression 

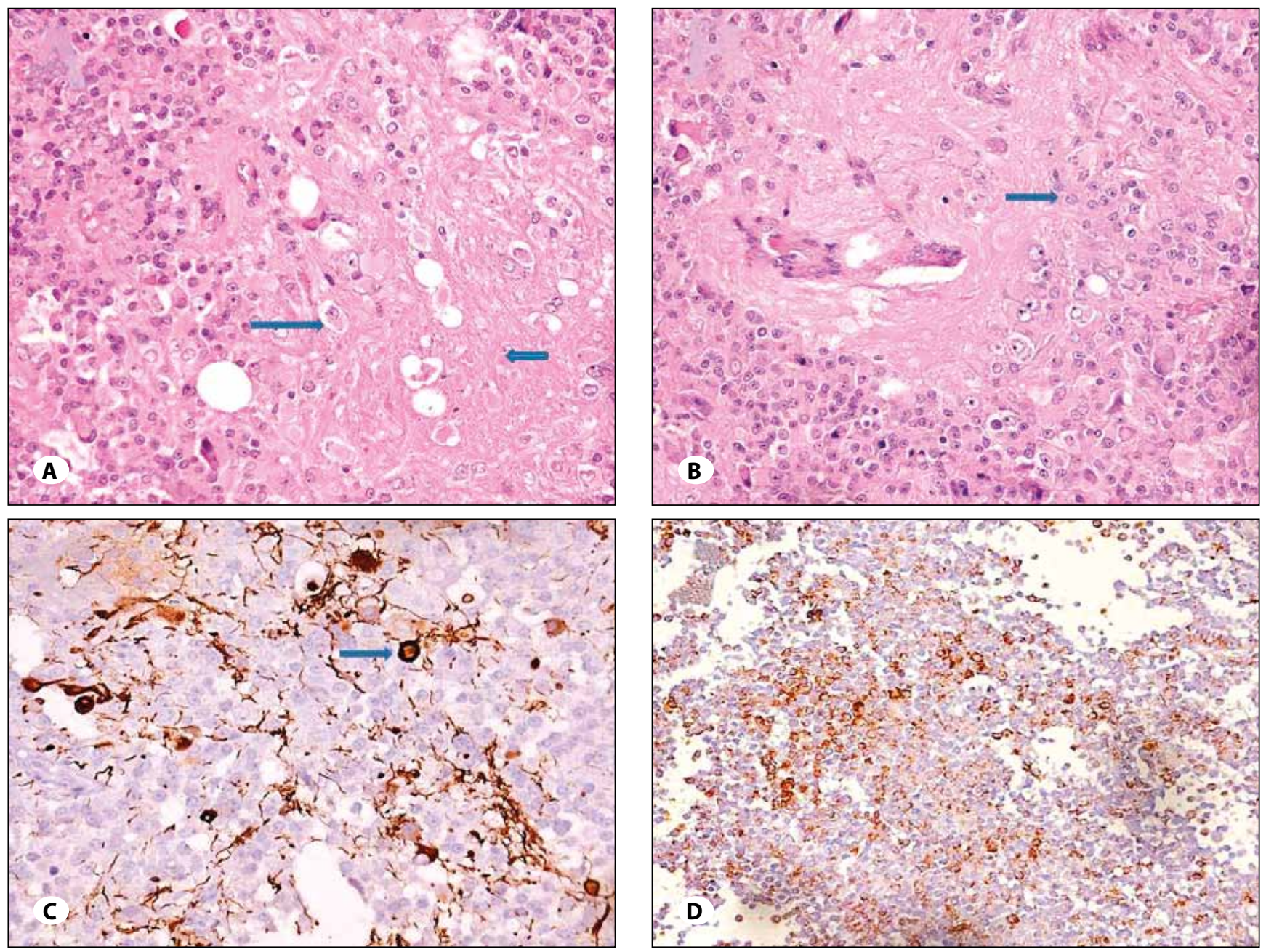

Figure 5: Photomicrograph of Case-2: A) Showing foci of neuronal cells (long arrow) with abundant neuropil (short arrow) in pituitary adenoma, B) Interface of pituitary adenoma and neuronal component (thick arrow), On immunohistochemistry, C) Ganglion cells (arrow) and neuropil are positive for neurofilament, D) Growth hormone positive tumor cells.
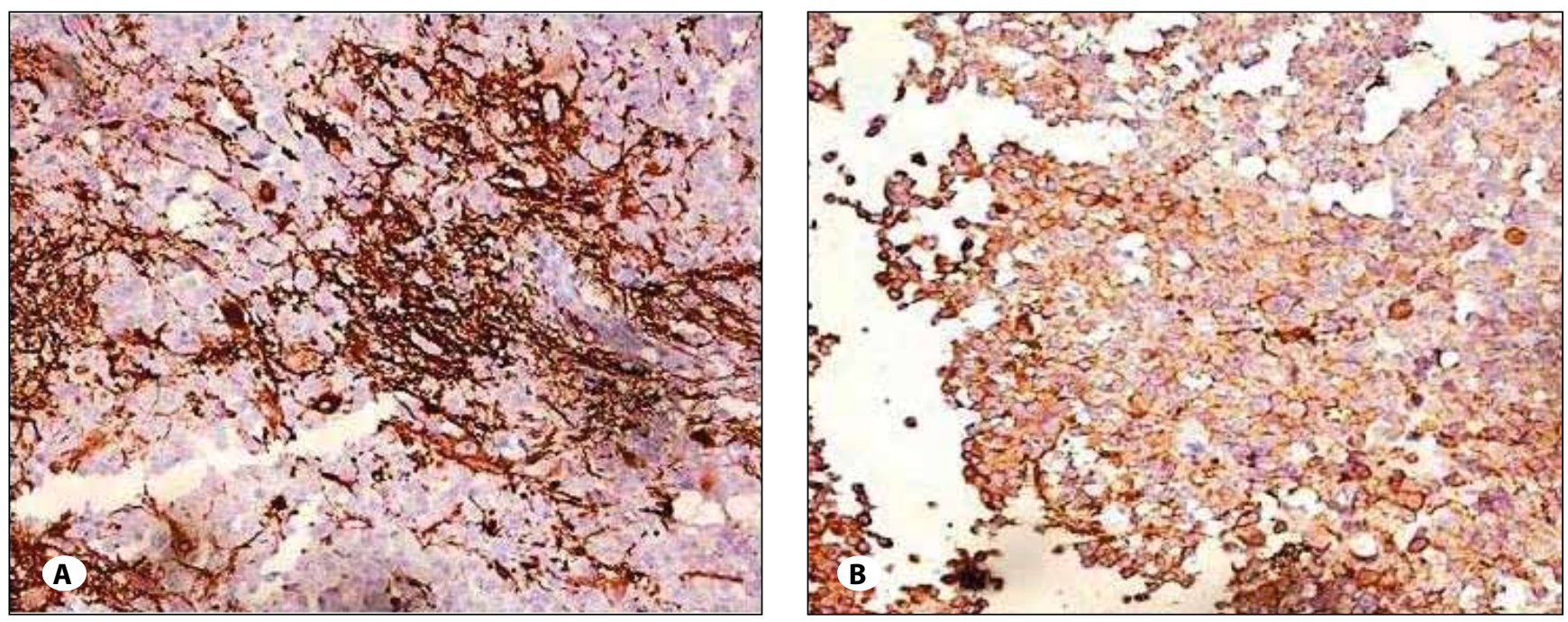

Figure 6: Photomicrograph of Case-2: On immunohistochemistry, tumor cells A) are positive for neuron specific enolase and B) positive for synaptophysin. 
effect may result in the proliferation of mesenchymal cells, including not only the moderate hyperplasia of interstitial fibroblasts but also the initiation of differentiation process of progenitor cells into the osteoblasts. Ke et al suggested that the effects of hyperprolactinemia in systemic circulation or the focal increase of autocrine prolactin concentration in the tumor parenchyma may also be candidates involved in the process of ossification within the interstitia of this prolactinoma (10). Since the osteoid metaplasia is also found in pituitary adenomas producing other hormones, such as $\mathrm{GH}$ and gonadotroph hormones, as in our case, it can be speculated that other non-prolactin-related mechanisms may also be involved in the ossifying metaplastic process in other cases. A pituitary adenoma associated with seizures should raise the possibility of intracranial pathology. The possibility of multiple primary brain tumors has been suggested earlier. On extensive review of the literature, we identified 4 case reports of pituitary adenoma with low grade glioma $(1,6,9,24)$. However, this is first case report of ossified pituitary adenoma with WHO grade II glioma. Fernades et al hypothesized that overexpression of insulin-like growth factor- 1 in cells induced by hormonal stimulation could signal the pathogenesis of astrocytic tumors and cause rapid progression (5). The presence of estrogen and progesterone receptors in one case lead to the conclusion that a common receptor substrate is involved.

Our second case is also reported rarely in he literature $(3,7,8,13,14,15,18,20,22,23)$. Gangliocytomas may arise in the hypothalamus immediately adjacent to the pituitary apart from the pituitary itself. These are rare lesions that do not have specific age or sex distribution and the exact etiology is also not known (2). The mechanism of neuronal transformation in pituitary adenoma remains obscure. Kiyono et al interpreted these neuronal cells as choristoma (12). Later on, three major hypotheses have been put forward (23). The first hypothesis proposes that proliferation of heterotopic intrasellar hypothalamic-like neurons gives rise to gangliocytoma. This theory was supported by morphologic and immunocytochemical similarity of the neural component to hypothalamic neurons. The second hypothesis attempts to explain the origin of the neuronal component from differentiation within sparsely granulated adenomas. Horvath et al noted the presence of intermediate cells between neurons and adenophyseal cells. Neuronal-like process were also noted in two cases (8). The third hypothesis proposes that both neuronal and adenohypophyseal elements originate from hypothalamic rests that may contain cells showing intermediate features between neurons and adenohypophyseal cells. These cells have been noted in pituitary gangliocytic tumors and not in normal pituitary gland may be because of the complex nature of the pituitary gland. This hypothesis seems to best explain the morphological and cytochemical features of the mixed as well as relatively pure gangliocytic sellar tumors.

Grossly these tumors do not have specific distinguishing features. Microscopically, the neuronal component may be inti- mately associated with pituitary adenoma, or may be present as two distinct components interspersed within the pituitary adenoma as seen in this case. Immunohistochemically, the ganglion cells are positive for synaptophysin, chromogranin and neurofilament while the neuropil is strongly positive for S-100 protein and GFAP (gilal fibrillary acidic protein) which specifically stains glial elements. Pituitary hormones may also be expressed in ganglion cells.

In conclusion, two unusual cases have been presented. To the best of our knowledge, our initial case is the first case of an astrocytoma presenting in a patient with acromegaly, harboring ossifying pituitary adenoma. Although no definite causative factors have been known for this extremely rare combination, a common factor must be looked into. The second case is of a mixed pituitary adenoma-gangliocytoma and was also a histological surprise. This is distinct entity consisting of mixed adenomatous and ganglion components.

\section{REFERENCES}

1. Abs R, Van Vyve M, Willems PJ, Neetens I, Van der Auwera B, Van den Ende E, Van de Kelft E, Beckers A, Van Marck E, Martin $\mathrm{JJ}$ :The association of astrocytoma and pituitary adenoma in a patient with alcaptonuria. J Neurol Sci 108:32-34, 1992

2. Asa S L, Kontogeorgos G, Sano T, Kovacs K, Lloyd RV, Trouillas J: Gangliocytoma In: DeLellis R A, Heitz P, Lloyd R V, Eng C eds, WHO Classification of Tumours of the Endocrine Organs: Pathology and Genetics of Endocrine Organs, Lyon: IARC Press, 2004, 40

3. Baysefer A, Gezen F, Kayali H, Erdoan E, Timurkaynak E, Celasun B: Intrasellar gangliocytoma resembling pituitary adenoma. Minim Invasive Neurosurg 40:107-109, 1997

4. Contran SR, Kumar V, Robbin SL: The endocrine system. In: Contran SR, Kumar V, Robbin SL, eds. Robbins' Pathologic Basis of Disease. Philadelphia, PA: Saunders, 1114-1121,1995

5. Fernandez A, Karavitaki N, Ansorge O, Fazal-Sanderson V, Wass JA: Acromegaly and anaplastic astrocytoma: Coincidence or pathophysiological relation? Pituitary 11:325-330, 2008

6. Furtado SV, Dadlani R, Ghosal N, Mahadevan A, Shankar SK, Hegde AS: Co-existing thyrotropin secreting pituitary adenoma and low grade glioma: Clinical considerations and literature review. J Neurosurg Sci 53:71-75, 2009

7. Halbauer J, Mészáros I, Dóczi T, Kajtár P, Pajor L, Kovács K, Gomori S: Rare sellar region tumors: Pathol Oncol Res 9: 134-137, 2003

8. Horvath E, Kovács K, Scheithauer BW, Lloyd RV, Smyth HS: Pituitary adenoma with neuronal choristoma (PANCH): Composite lesion or lineage infidelity? Ultrastruct Pathol 18:565-574, 1994

9. Inagawa S, Yamakawa H, Nishikawa M: Triple primary brain tumors of different histological types: Case report. Surg Neurol 41:52-55, 1994

10. Ke C, Deng Z, Lei T, Zhou S, Guo D, Wan J, Wu S: Pituitary prolactin producing adenoma with ossification: A rare histological variant and review of literature. Neuropathology 30(2):165-169, 2010, Epub 2009 Sep 7 
11. Khosla S, Westendorf JJ, Oursler MJ: Building bone to reverse osteoporosis and repair fractures. J Clin Invest 118:421-428, 2008

12. Kiyono $\mathrm{H}$ : histopatholologie der hypophyse. Virchow archives. A Patholo Anat Histopathol 259:388-465, 1926

13. Kontogeorgos G, Mourouti G, Kyrodimou E, Liapi-Avgeri G, Parasi E: Ganglion cell containing pituitary adenomas: Signs of neuronal differentiation in adenoma cells Acta Neuropathol 2112:21-28, 2006

14. Kurosaki M, Saeger W, Ludecke DK: Intrasellar gangliocytomas associated with acromegaly Brain Tumor Pathol 19:63-67, 2002

15. Kuroiwa $\mathrm{T}$, Ohta $\mathrm{T}$, Kobata $\mathrm{H}$, Yamamoto $\mathrm{H}$, Kimura $\mathrm{N}$ : Coexistence of intracranial meningioma and primary malignant lymphoma--case report. Neurol Med Chir 30: 268-271, 1990

16. Mukada K, Ohta M, Uozumi T, Arita K, Kurisu K, Inai K: Ossified prolactinoma: A case report. Neurosurg 20:473-475, 1987

17. Palaoglu S, Bavbek M, Peker S Onol B, Sungur A, Erbengi A: Ossified somatotrophinoma Surg Neurol 41:143-146, 1994

18. Puchner MJ, Ludecke DK, Saeger W, Riedel M, Asa SL: Gangliocytomas of the sellar region: A review. Exp Clin Endocrinol Diabetes 103:129-149, 1995

19. Roncaroli F, Fioravanti A, Marliani AF, Calbucci F: Osseous metaplasia in a growth hormone-secreting pituitary adenoma. Clin Neuropathol 18:205-207, 1999
20. Saeger W, Ludecke DK, Losa M: Combined neuronal and endocrine tumors of the sellar region. Pathologe 18:419-424, 1997

21. Shanklin WM: On the presence of calcific bodies, cartilage, bone, follicular concretions and the so-called hyaline bodies in the human pituitary. Anat Rec 102:469-491, 1948

22. Sharma MC, Karak AK, Mahapatra AK, Sarkar C: Pituitary adenoma with neuronal choristoma: A report of two rare cases Clin Neurol Neurosurg 101:128-132, 1999

23. Towfighi J, Salam MM, McLendon RE, Powrs S, Page RB: Ganglion cell-containing tumors of the pituitary gland. Arch Pathol Lab Med 120:369-377, 1996

24. Tsibel' BN, Solodun luV: Case of combined malignant adenoma of the hypophysis and astrocytoma. Arkh Pathol 47:60-62, 1985

25. Webster J, Peters JR, John R, Smith J, Chan V, Hall R, Scanlon MF: Pituitary stone: Two cases of densely calcified thyrotrophinsecreting pituitary adenomas. Clin Endocrinol 40:137-143, 1994

26. Zahariadis G, Kontogeorgos G, Liberopoulos K George S, Kovacs K: Ossifying pituitary gonadotroph adenoma: A case report. Acta Neurochir (Wien) 141: 1001-1004, 1999 